\title{
Preferensi Habitat Ikan Gabus [Channa striata (Bloch 1793)] di Perairan Rawa Aopa, Sulawesi Tenggara
}

\section{(Habitat Preferences of Striped Snakehead [Channa striata (Bloch 1793)] in the Rawa Aopa Water, Southeast Sulawesi)}

\author{
Muliani $^{1}$, Asriyana ${ }^{2,3^{\star}}$, Muhammad Ramli ${ }^{4}$ \\ (Diterima November 2020/Disetujui September 2021)
}

\begin{abstract}
ABSTRAK
Pemanfaatan habitat oleh ikan berkait erat dengan upaya mencari kondisi terbaik bagi kelangsungan hidupnya. Penelitian ini bertujuan mendeskripsikan preferensi habitat ikan gabus di perairan Rawa Aopa, Sulawesi Tenggara. Penelitian dilaksanakan pada bulan November 2018 sampai Februari 2019 di perairan tersebut. Ikan dikoleksi menggunakan alat tangkap bubu. Preferensi ikan gabus terhadap tipe habitat ditentukan dengan analisis indeks constancy dan fidelity. Sebanyak 1.024 ekor ikan gabus tertangkap dengan panjang 200,0-420,0 mm dan bobot 69,0-596,0 g. Ikan gabus berukuran 200-367 mm konsisten dalam menempati habitat dengan kerapatan tumbuhan air agak rapat hingga rapat, sedangkan ukuran 368-388 dan 389-430 mm konsisten pada habitat dengan kerapatan tumbuhan air yang jarang. Tingkat kesukaan ikan gabus ukuran $\mathbf{3 8 9 - 4 3 0 ~} \mathrm{mm}$ terhadap habitat dengan tumbuhan air jarang sangat tinggi $\left(F_{i j}=6\right)$ dan dapat dijadikan sebagai indikator pada habitat dengan kategori tumbuhan air jarang. Kesukaan ikan gabus ukuran 200-367 mm terhadap habitat dengan tumbuhan air yang rapat mengindikasikan bahwa habitat tersebut merupakan daerah untuk mencari makanan, pembesaran, dan perlindungan.
\end{abstract}

Kata kunci: Channa striata, habitat ikan, ikan gabus, Rawa Aopa, Sulawesi Tenggara

\section{ABSTRACT}

The use of habitat by fish is closely related to efforts to find the best conditions for the survival of these fish. This study aims to analyze the habitat preferences of Striped snakehead in Rawa Aopa waters, Southeast Sulawesi. This research was conducted from November 2018 to February 2019 in the waters of Swamp Aopa Southeast Sulawesi. Fish collection using traps. The constancy and fidelity index determined the preference of striped snakehead for habitat type. A total of 1024 striped snakehead fish were caught during the study with a length range of 200,0-420,0 $\mathrm{mm}$ and 69,0-596,0 g weight. Striped snakehead measuring 200-367 mm were consistent in occupying habitats with a slightly dense to dense water plant density, while sizes $368-388$ and $389-430 \mathrm{~mm}$ were consistent in habitats with sparse water plant density. The preference level of striped snakehead fish size $389-430 \mathrm{~mm}$ to habitats with rare aquatic plants is very high (Fij = 6). Therefore, the size can be used as an indicator of habitats with the rare aquatic plant category. The preference for $200-367 \mathrm{~mm}$ striped snakehead fish in dense aquatic plant habitats indicates that these habitats are foraging, growing, and protective zones.

Keywords: Channa striata, fish habitat, Rawa Aopa, Southeast Sulawesi, stripe snakehead

\section{PENDAHULUAN}

Channa striata (Bloch 1793) yang lebih dikenal dengan nama ikan gabus merupakan salah satu ikan tawar yang banyak digemari masyarakat. Selain rasa

1 Program Studi IImu Perikanan, Pascasarjana, Universitas Halu Oleo. Kampus Abdullah Silondae, Jl. Mayjend S. Parman, Kemaraya, Kendari, Sulawesi Tenggara, 93121

2 Jurusan Manajemen Sumberdaya Perairan, Fakultas Perikanan dan IImu Kelautan, Universitas Halu Oleo. Kampus Bumi Tridharma, Anduonohu, Kendari, Sulawesi Tenggara, 93232

${ }^{3}$ Masyarakat Iktiologi Indonesia, Jl. Raya Jakarta-Bogor Km 46, Cibinong, Bogor, 16911

4 Jurusan IImu Kelautan, Fakultas Perikanan dan IImu Kelautan, Universitas Halu Oleo. Kampus Bumi Tridharma, Anduonohu, Kendari, Sulawesi Tenggara, 93232

* Penulis Korespondensi: Email: asriyana@uho.ac.id yang enak karena tekstur dagingnya yang putih dan tebal serta cita rasa yang khas, ikan gabus mengandung protein tinggi dan sering dijadikan bahan obat. Kandungan yang dimiliki ini sangat baik untuk menjaga kesehatan akibat tingginya kandungan protein, albumin, asam lemak esensial, mineral zink, dan kolagen sehingga dapat digunakan di industri pangan maupun non-pangan termasuk untuk memproduksi peptida bioaktif (Mustafa et al. 2012). Secara klinis, konsentrat protein ikan gabus dalam bentuk suplemen berfungsi sebagai antioksidan dan antidiabetes, serta dapat membantu mempercepat penyembuhan pasien pasca-operasi, luka bakar, dan stroke pada pasien rawat inap di rumah sakit (Prastari et al. 2017; Hidayati et al. 2018; Rosyidi et al. 2019; Suhendi et al. 2020). Ikan gabus tersebar luas dari China, Asia Selatan, dan Asia Tenggara (Froese \& Pauly 2018; Lalramliana et al. 2018). 
Taman Nasional Rawa Aopa Watumohai (TNRAW) merupakan kawasan konservasi yang mayoritas masyarakat sekitarnya bergantung pada berbagai potensi sumber daya alam yang terdapat di dalam kawasan. Salah satu potensi sumber daya alam yang sering dimanfaatkan oleh masyarakat di sekitar taman nasional adalah ikan gabus. Pengoperasian bubu dalam penangkapan ikan gabus oleh masyarakat hanya didasarkan pada kebiasaan turun temurun tanpa memerhatikan kondisi habitat yang disukai oleh ikan gabus seperti tempat memijah, berkembang biak, dan tempat hidupnya sehingga sering kali ikan yang tertangkap berukuran kecil dan bahkan ada yang tertangkap dalam keadaan matang gonad. Habitat yang menjadi tempat hidup ikan gabus menjadi perhatian penting karena dengan mengenal preferensi habitat, nelayan dapat menangkap ikan gabus secara optimum dengan tetap menjaga keberlanjutan sumber daya tersebut. Informasi kondisi habitat sangat di butuhkan dalam mengelola ikan gabus guna menjaga kelestariannya.

Ikan gabus telah banyak diteliti terkait segi distribusi (Froese \& Pauly 2018), kandungan gizi (Prastari et al. 2017; Hidayati et al. 2018), kebiasaan makan (WardCampbell \& Beamish 2005; Li et al. 2016; Arsyad et al. 2018); pertumbuhan dan produktivitas (Borah et al. 2018; Taufikir et al. 2018), dan biologi reproduksi (Anwar et al. 2018; Irmawati et al. 2019; Bahrin et al. 2020), tetapi informasi terkait habitat yang disukai relatif terbatas. Keterkaitan antara kelimpahan ikan gabus dan tumbuhan air cukup besar seperti yang dilaporkan oleh Sirodiana \& Irawan (2017); Djumanto et al. (2018). Oleh karena itu diperlukan informasi terkait habitat spesifik yang disukai oleh ikan ini berdasarkan ukuran di perairan yang ditumbuhi oleh tanaman air. Penelitian ini bertujuan mendeskripsikan preferensi habitat ikan gabus di perairan Rawa Aopa, Sulawesi Tenggara.

\section{METODE PENELITIAN}

Penelitian dilaksanakan di Perairan Rawa Aopa Desa Puriala Kabupaten Konawe, Provinsi Sulawesi Tenggara. Ikan gabus ditangkap dua kali dalam sebulan dari bulan November 2018 sampai Februari 2019. Lokasi penangkapan adalah pada posisi koordinat $4^{\circ} 6^{\prime} 30^{\prime \prime}-4^{\circ} 6^{\prime} 34^{\prime \prime}$ LS dan $122^{\circ} 4^{\prime} 4^{\prime \prime}-122^{\circ} 5^{\prime} 35^{\prime \prime}$ BT (Gambar 1), pada tiga stasiun yang dibedakan berdasarkan karakteristik tumbuhan air yang hidup di perairan tersebut seperti jenis dan kerapatannya.

\section{Data yang Dikumpulkan dan Alat yang Digunakan}

Data kondisi habitat ikan gabus yang diukur meliputi: suhu, $\mathrm{pH}$, oksigen terlarut, dan kerapatan tumbuhan air. Sementara data biologi ikan yang diukur meliputi panjang total, bobot ikan, dan jumlah ikan yang tertangkap. Alat yang digunakan saat penelitian tertera pada Tabel 1.

\section{Pengambilan Data}

Kondisi habitat berupa suhu, $\mathrm{pH}$, dan oksigen terlarut diukur langsung di lapangan (Tabel 1) sementara kerapatan tumbuhan air diukur dengan menggunakan transek kuadrat ukuran $1 \mathrm{~m} \times 1 \mathrm{~m}$ di setiap stasiun penelitian. Jenis dan jumlah individu tumbuhan air dicatat sedangkan jenis tumbuhan air yang belum diketahui jenisnya dikumpulkan untuk diidentifikasi lebih lanjut di laboratorium dengan merujuk Pancho \& Soedani (1978). Kondisi habitat diukur saat pagi hari (pukul 09.00 WITA) sebelum pengoperasian alat tangkap bubu.

Ikan di setiap stasiun penelitian ditangkap dua kali dalam sebulan dengan menggunakan alat tangkap bubu berukuran $50 \times 40 \times 50 \mathrm{~cm}^{3}$, ukuran mata jaring 3 inci, dan ukuran lebar bukaan pintu $8 \mathrm{~cm}$ (Gambar 2). Alat tangkap tersebut tidak dioperasikan menggunakan umpan. Bubu diletakkan di perairan menggunakan alat

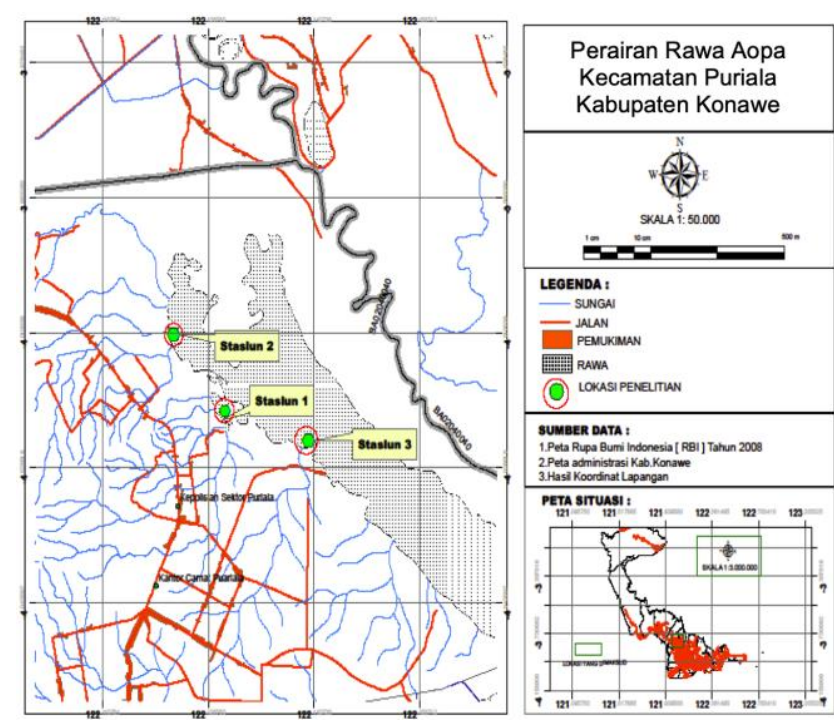

Gambar 1 Lokasi penelitian perairan Rawa Aopa

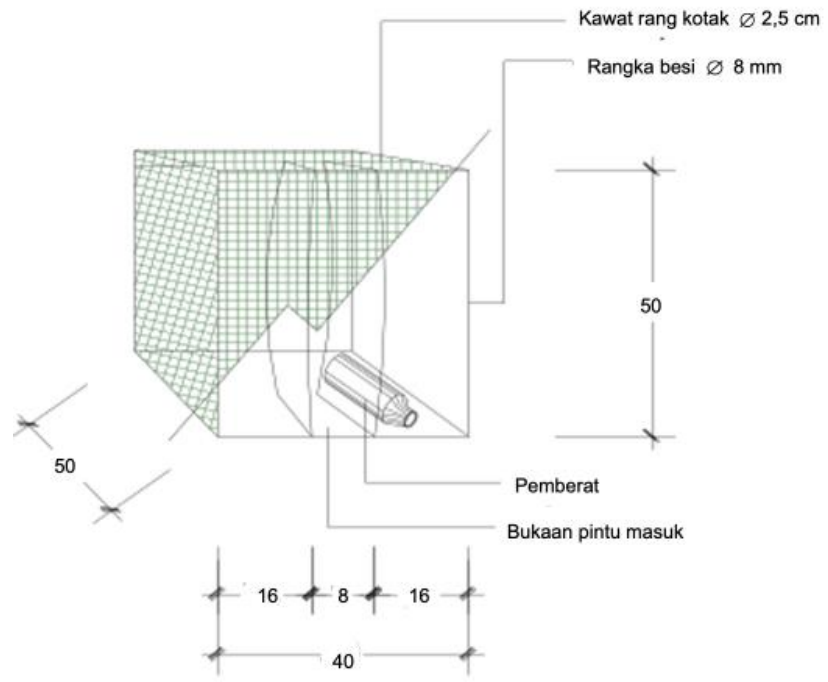

Gambar 2 Alat tangkap bubu yang dioperasikan saat penelitian 
bantu sampan untuk bergerak antar-stasiun. Sebanyak 10 buah bubu dioperasikan di setiap stasiun dengan jarak 5-10 m dan didiamkan di perairan selama dua hari.

Sampel ikan yang terkumpul dipisahkan berdasarkan stasiun pengambilan dan dimasukkan ke dalam coolbox yang berisi butiran es untuk dianalisis lebih lanjut di Laboratorium Fakultas Perikanan dan Ilmu Kelautan, Universitas Halu Oleo. Di laboratorium, sampel ikan diidentifikasi menurut Kottelat et al. (1993) dan Froese \& Pauly (2018). Selanjutnya setiap individu ikan diukur panjangnya menggunakan mistar dengan tingkat ketelitan $1 \mathrm{~mm}$ dan bobot ditimbang menggunakan timbangan analitik dengan ketelitian 0,1 g. Dalam penelitian ini, ikan gabus tidak dibedakan berdasarkan seksnya. Sebaran ukuran ikan yang tertangkap ditentukan dengan membuat distribusi interval kelas berdasarkan aturan Sturges (1926). Selanjutnya data ditabulasi berdasarkan kelompok ukuran, stasiun, dan jumlah individu yang tertangkap. Kerapatan tumbuhan air dinyatakan sebagai jumlah individu per satuan luas yang dinyatakan dalam satuan meter persegi sesuai dengan petunjuk Brower et al. (1990).

Preferensi ikan gabus terhadap tipe habitat ditentukan melalui analisis Nodal yang didasarkan pada indeks constancy dan fidelity. Dalam analisis ini tingkat kesamaan antar-habitat terlebih dahulu ditentukan berdasarkan parameter fisik-kimia air dan kerapatan tumbuhan air. Kesamaan antar-habitat merujuk pada indeks Canberra (Krebs 1989). Analisis kesama- an kelompok ukuran ikan gabus ditentukan melalui indeks Sorensen Similarity (Legendre \& Legendre 1983) yang didasarkan atas keberadaan dan ketidakberadaan (present-absent) suatu kelompok ukuran dengan kelompok ukuran lainnya di setiap stasiun.

Keterkaitan antar-kelompok ukuran dan habitat ikan gabus kemudian dikelompokkan dalam bentuk dendogram. Hasil pengelompokan tersebut dikombinasikan dalam data matriks biner, yaitu kelompok zona menempati lajur sedangkan kelompok ukuran ikan gabus sebagai baris. Selanjutnya ditentukan nilai indeks constancy dan fidelity setiap komponen matriks (modifikasi La Sara \& Asriyana 2012). Kriteria nilai indeks constancy $\left(\mathrm{C}_{\mathrm{ij}}\right)$ adalah sebagai berikut. Nilai $\mathrm{C}_{i j}$ $=1$ berarti ikan ke- $i$ terdapat pada habitat ke-j, dan nilai $\mathrm{C}_{i j}=0$ menunjukkan ikan ke- $i$ tidak terdapat pada kelompok habitat ke-j. Sementara kriteria indeks fidelity adalah sebagai berikut: nilai $F_{i j} \geq 2$ menunjukkan preferensi yang kuat antara ukuran ikan ke-i dengan habitat ke-j; $F_{i j}<1$ menunjukkan tingkat ketidaksukaan (avoidance) ikan ke-i terhadap habitat ke-j.

\section{HASIL DAN PEMBAHASAN}

\section{Kondisi Habitat}

Kondisi habitat perairan Rawa Aopa berdasarkan parameter kualitas air relatif seragam, kecuali jenis dan kerapatan tumbuhan air (Tabel 2). Kisaran suhu habitat di setiap stasiun adalah $29,0-35^{\circ} \mathrm{C}$ dengan rataan

Tabel 1 Data yang diukur saat penelitian

\begin{tabular}{lcll}
\hline \multicolumn{1}{c}{ Jenis Data } & Unit & & Alat \\
\hline Habitat: & & & Lokasi \\
Suhu air & ${ }^{\circ} \mathrm{C}$ & Termometer digital & Lapangan \\
pH air & - & $\mathrm{pH}$ meter, merk Hanna Digital HI 98107 & Lapangan \\
Oksigen terlarut & $\mathrm{mg} \cdot \mathrm{L}^{-1}$ & DO meter, merk Lutron DO-5510 & Lapangan \\
Kerapatan tumbuhan air & $\mathrm{Ind} \cdot \mathrm{m}^{-2}$ & Transek kuadrat & Lapangan \\
Jenis tumbuhan air & spesies & Buku identifikasi & Laboratorium \\
$\begin{array}{l}\text { Posisi koordinat } \\
\text { Biologi lkan: }\end{array}$ & derajat & GPS, merk Garmin eTrex 10 & Lapangan \\
Jumlah & & & \\
Jenis & ekor & Bubu, sampan & Lapangan \\
Panjang total & species & Buku indentifikasi & Laboratorium \\
Bobot & $\mathrm{mm}$ & Mistar ukur ikan & Laboratorium \\
\end{tabular}

Tabel 2 Kondisi habitat ikan gabus di perairan Rawa Aopa

\begin{tabular}{|c|c|c|c|c|c|}
\hline \multirow[t]{2}{*}{ Stasiun } & Suhu $\left({ }^{\circ} \mathrm{C}\right)$ & $\mathrm{pH}$ & $\begin{array}{c}\text { Oksigen terlarut } \\
\left(\mathrm{mgl}^{-1}\right)\end{array}$ & $\begin{array}{l}\text { Kerapatan } \\
\text { tumbuhan air }\end{array}$ & \multirow[t]{2}{*}{ Jenis tumbuhan air } \\
\hline & Kisaran & Kisaran & Kisaran & (Ind. $\left.\mathrm{m}^{-2}\right)$ & \\
\hline $\mathrm{I}$ & $30,0-33,0$ & $7,5-7,8$ & $4,1-4,4$ & $211,0-245,0$ & $\begin{array}{l}\text { Pandan air, tumbuhan paku, } \\
\text { spirogira, teratai, genjer }\end{array}$ \\
\hline Rataan \pm SD & $31,1 \pm 1,3$ & $7,6 \pm 0,2$ & $4,18 \pm 2,2$ & $227,8 \pm 11,3$ & \\
\hline II & $29,0-35,0$ & $7,1-7,6$ & $3,7-4,0$ & $83,0-144,0$ & $\begin{array}{l}\text { Pandan air, tumbuhan paku, } \\
\text { spirogyra, teratai, genjer, } \\
\text { pakis }\end{array}$ \\
\hline Rataan \pm SD & $32,3 \pm 2,5$ & $7,3 \pm 0,2$ & $3,9 \pm 0,1$ & $113,0 \pm 21,2$ & \\
\hline III & $29,0-35,0$ & $7,1-7,9$ & $3,3-3,5$ & $22,0-27,0$ & $\begin{array}{l}\text { Pandan air, spirogira, } \\
\text { genjer, teratai, pakis }\end{array}$ \\
\hline Rataan \pm SD & $32,6 \pm 2,8$ & $7,5 \pm 0,4$ & $3,4 \pm 0,1$ & $25,0 \pm 1,6$ & \\
\hline
\end{tabular}


$31,1-32,6^{\circ} \mathrm{C}$. Ikan gabus di perairan Rawa Pening mempunyai preferensi habitat terhadap suhu 27,4-27, $9^{\circ} \mathrm{C}$ (Djumanto et al. 2018), lebih rendah daripada suhu perairan di Rawa Aopa. Suhu air memengaruhi kelangsungan hidup ikan gabus, mulai dari penetasan dan perkembangan telur, benih, sampai ukuran dewasa (Muslim et al. 2018; Ridho et al. 2019). Sementara kisaran oksigen terlarut dan $\mathrm{pH}$ tidak jauh berbeda dari parameter tersebut yang menjadi habitat yang disukai oleh ikan gabus seperti yang dilaporkan Djumanto et al. (2018) di perairan Rawa Pening, yaitu berturut-turut 3,33-5,21 mg/L dan 7,07-7,38. Spesies ikan ini merupakan organisme dengan daya toleransi yang tinggi terhadap lingkungan. Ikan tersebut dapat hidup dalam kondisi yang ekstrem (rawa dengan kondisi kering) dengan cara membenamkan dirinya dalam lumpur (Muslim et al. 2018). Selain itu dengan organ pernapasan tambahan, ikan gabus mampu menghirup udara langsung dari atmosfer sehingga mampu bertahan pada kondisi perairan dengan konsentrasi oksigen terlarut yang rendah (Chandra \& Banerjee 2004) bahkan dapat bertahan hidup tanpa air, seperti yang dilaporkan juga pada jenis Channa argus (Duan et al. 2018).

Tumbuhan air yang ditemukan di perairan Rawa Aopa terdiri atas enam jenis, yaitu pandan air (Pontederia cordata), tumbuhan paku (Pteridophyta), pakis (Chychas rumpii), spirogira (Spyrogira sp.), teratai (Nymphae sp.), dan genjer (Limnocharis flava). Kerapatan setiap jenis tersebut relatif beragam. Ikan gabus di perairan Rawa Pening banyak ditemukan di perairan dengan persentase tutupan vegetasi $80 \%$ (Djumanto et al. 2018). Hal yang sama juga ditemukan di perairan Rawa Aopa, yakni ikan gabus lebih banyak ditemukan pada stasiun dengan kerapatan tumbuhan air yang tinggi, yaitu $83,0-245$ ind. $\mathrm{m}^{-2}$. Selain itu, ikan ini juga memiliki produktivitas dan kelangsungan hidup yang tinggi jika berada pada perairan dengan tumbuhan air dari jenis kangkung (Ipomoea aquatica) daripada tanpa tumbuhan air (Ngoc Bich et al. 2020).

Dalam penelitian ini, parameter kualitas air tidak digunakan sebagai parameter pengelompokan habitat karena kondisi kualitas air relatif seragam antar-stasiun dengan tingkat kemiripan antar-stasiun $>96,0 \%$, sementara parameter tumbuhan air mempunyai tingkat kemiripan yang rendah, yaitu $<50 \%$. Berdasarkan parameter kondisi tumbuhan air, perairan Rawa Aopa terbentuk dalam dua kelompok habitat, yaitu habitat $A$ yang merupakan gabungan antara stasiun I dan II dengan tingkat kemiripan $53,04 \%$, dan habitat B yang hanya terdiri atas satu stasiun, yaitu Stasiun III (Gambar 3). Habitat A merupakan perairan dengan kondisi kerapatan air dalam kategori agak rapat sampai sangat rapat (Braun-Blanquet 1965; Gosari \& Haris 2012) dengan kerapatan 75 sampai $>175$ ind. $\mathrm{m}^{-2}$, sementara habitat $B$ merupakan perairan dengan kategori kerapatan tumbuhan air jarang hingga sangat jarang (kerapatan $<75$ ind. $\mathrm{m}^{-2}$ ).

\section{Sebaran Ukuran}

Ikan gabus yang tertangkap saat penelitian sebanyak 1.024 ekor dengan panjang 200,0-420,0 mm dan bobot 69,0-596,0 g. Sebaran ukuran panjang tertera pada Tabel 3. Ukuran panjang 200-241 mm merupakan frekuensi tertinggi $(25,58 \%$ dan $22,75 \%)$. Ukuran ikan yang tertangkap saat penelitian beragam seperti yang dilaporkan di beberapa lokasi (Tabel 4). Keragaman ukuran ikan yang tertangkap tersebut dipengaruhi oleh keragaman alat tangkap yang digunakan, musim, perbedaan habitat, dan kondisi lingkungan. Beberapa peneliti melaporkan bahwa ukuran ikan yang tertangkap dapat berbeda-beda dan berubah yang disebabkan oleh tingkat kematangan gonad, jenis kelamin, dan musim pemijahan (Asriyana \& Halili 2021); perbedaan habitat, kondisi lingkungan, dan ketersediaan makanan (Asriyana et al. 2018). Dengan demikian, ketersediaan sumber makanan dan kondisi lingkungan yang baik menyebabkan ikan akan tumbuh dengan baik dan keragaman ukurannya akan berbeda.

Umumnya ukuran dominan yang tertangkap (200-241 mm) merupakan ukuran ikan gabus yang
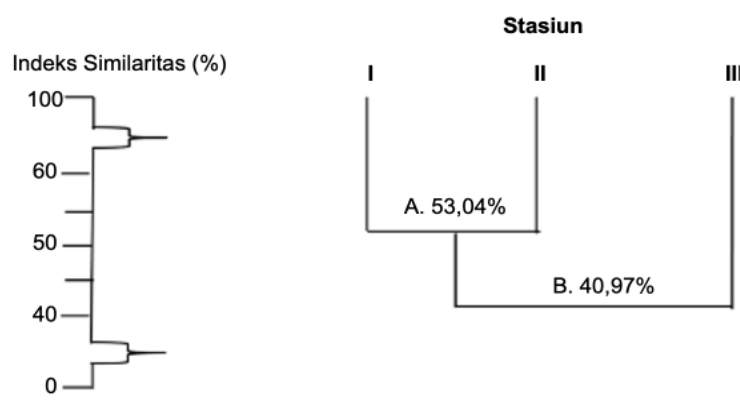

Gambar 3 Pengelompokan habitat ikan gabus berdasarkan kerapatan tumbuhan air di perairan Rawa Aopa

Tabel 3 Sebaran ukuran ikan gabus yang tertangkap saat penelitian di perairan Rawa Aopa

\begin{tabular}{|c|c|c|c|c|c|}
\hline \multirow{2}{*}{$\begin{array}{c}\text { Kelompok } \\
\text { ukuran }(\mathrm{mm})\end{array}$} & \multicolumn{3}{|c|}{ Stasiun } & \multirow{2}{*}{$\begin{array}{l}\text { Total } \\
\text { (ind.) }\end{array}$} & \multirow{2}{*}{$\begin{array}{c}\text { Frekuensi } \\
(\%)\end{array}$} \\
\hline & 1 & 2 & 3 & & \\
\hline $200-220$ & 175 & 65 & 22 & 262 & 25,58 \\
\hline $221-241$ & 93 & 124 & 16 & 233 & 22,75 \\
\hline 242-262 & 49 & 39 & 4 & 92 & 8,98 \\
\hline 263-283 & 61 & 54 & 1 & 116 & 11,37 \\
\hline 284-304 & 58 & 34 & 0 & 92 & 8,98 \\
\hline $305-325$ & 61 & 33 & 3 & 97 & 9,47 \\
\hline $326-346$ & 20 & 19 & 2 & 41 & 4,00 \\
\hline $347-367$ & 55 & 11 & 1 & 67 & 6,54 \\
\hline 368-388 & 20 & 0 & 2 & 22 & 2,15 \\
\hline 389-409 & 0 & 0 & 1 & 1 & 0,09 \\
\hline $410-430$ & 0 & 0 & 1 & 1 & 0,09 \\
\hline Jumlah & 592 & 379 & 53 & 1024 & 100,00 \\
\hline
\end{tabular}

Keterangan: $\mathrm{sb}=$ simpangan baku 
telah matang gonad, sementara ukuran $<200 \mathrm{~mm}$ tidak ditemukan saat penelitian. Makmur et al. (2003) melaporkan bahwa di perairan Sungai Musi, Sumatera Selatan, ikan gabus jantan dan betina berukuran 154 dan $180 \mathrm{~mm}$ TL sudah mulai matang gonad, demikian pula ikan gabus yang ditemukan di Sungai Bojo, Kabupaten Barru, matang gonad pertama kali saat berukuran 115,60 cm TL dan di lahan basah Bantaeng berukuran 230,00 mm TL (Irmawati et al. 2019). Hal ini mengindikasikan bahwa saat penelitian di perairan Rawa Aopa, umumnya ikan gabus berada dalam fase perkembangan gonad. Tidak ditemukannya ikan gabus yang berukuran kecil berhubungan dengan penggunaan alat tangkap yang selektif dengan ukuran mata jaring 3 inci sehingga ikan berukuran kecil dapat lolos.

Berdasarkan keberadaan dan ketidakberadaan (present-absent) suatu kelompok ukuran dengan kelompok ukuran lainnya di setiap stasiun, kelompok ukuran ikan gabus yang ditemukan di perairan Rawa Aopa terbagi dalam tiga kelompok ukuran (Gambar 4). Kelompok ukuran pertama merupakan ikan berukuran 200-367 mm. Kelompok ukuran kedua berukuran panjang 368-388 mm, dan kelompok ketiga berukuran 389-430 mm. Kesamaan ukuran yang berada dalam satu kelompok menunjukkan bahwa ikan-ikan tersebut mempunyai kesamaan habitat saat tertangkap.

\section{Preferensi Habitat}

Matriks data biner yang mengombinasikan antara kelompok habitat dan kelompok ukuran tertera pada Gambar 5A. Setiap kelompok ukuran tersebut menempati habitat yang beragam sehingga memengaruhi proporsi nilai constancy dan fidelity dalam menentukan tingkat kekonsistenan dan kesukaan ikan gabus akan habitat di perairan Rawa Aopa (Gambar 5B).

Ikan ukuran 200-367 mm terlihat menempati habitat $A$ dengan konsisten $\left(C_{i j}=1\right)$ dan tidak konsisten pada habitat $B\left(C_{i j<1}\right)$. Hal ini berarti ikan dengan ukuran tersebut selalu ditemukan pada habitat dengan kerapatan tumbuhan air yang agak rapat hingga sangat rapat. Sementara pada habitat dengan tumbuhan air yang jarang tidak selalu ditemukan. Ikan gabus merupakan ikan karnivora yang menyukai makanan seperti invertebrata air, katak, ikan, reptil, udang, dan insekta air (Ward-Campbell \& Beamish 2005; Li et al. 2016), gastropoda, zooplankton, dan ikan (Arsyad et al. 2018) yang hidup berasosiasi dengan tumbuhan air. Selain itu, ikan ini memangsa hewan lainnya yang bersembunyi di sekitar tumbuhan air, seperti yang dilaporkan oleh Moyle \& Cech (2000); Weliange \& Amarasinghe (2007) bahwa ikan dengan bentuk kepala pipih seperti $C$. striata merupakan kelompok ikan predator pasif yang menunggu mangsanya. Tumbuhan air yang rapat selain berfungsi sebagai daerah perlindungan, juga berfungsi sebagai daerah tempat mencari makanan. Sirodiana \& Irawan (2017) melaporkan bahwa ikan gabus berukuran juwana yang hidup pada daerah dengan perlakuan naungan tumbuhan air memperlihatkan pertambahan panjang, bobot, dan sintasan yang cukup tinggi (78\%). Penem-
Tabel 4 Ragam ukuran ikan gabus di beberapa lokasi

\begin{tabular}{rll}
\hline $\begin{array}{c}\text { Ukuran } \\
(\mathrm{mm})\end{array}$ & \multicolumn{1}{c}{ Lokasi } & \multicolumn{1}{c}{ Pustaka } \\
\hline $229-424$ & India & Dayal et al. (2012) \\
$106-393$ & Pearl River, China & Li et al. (2013) \\
$153-279$ & Rawa Lebak Sekayu & Muthmainnah (2013) \\
$144-269$ & Rawa Lebak Mariana & Muthmainnah (2013) \\
$100-200$ & Sigi, Sulawesi Tengah & Serdiati et al. (2013) \\
$38-231$ & Sigi, Sulawesi Tengah & Nodobe et al. (2014) \\
$39-395$ & Rawa Aopa & Arsyad et al. (2018) \\
$211-469$ & Rawa Aopa & Taufikir et al. (2018) \\
$200-220$ & Rawa Aopa & Penelitian ini (2020) \\
\hline
\end{tabular}

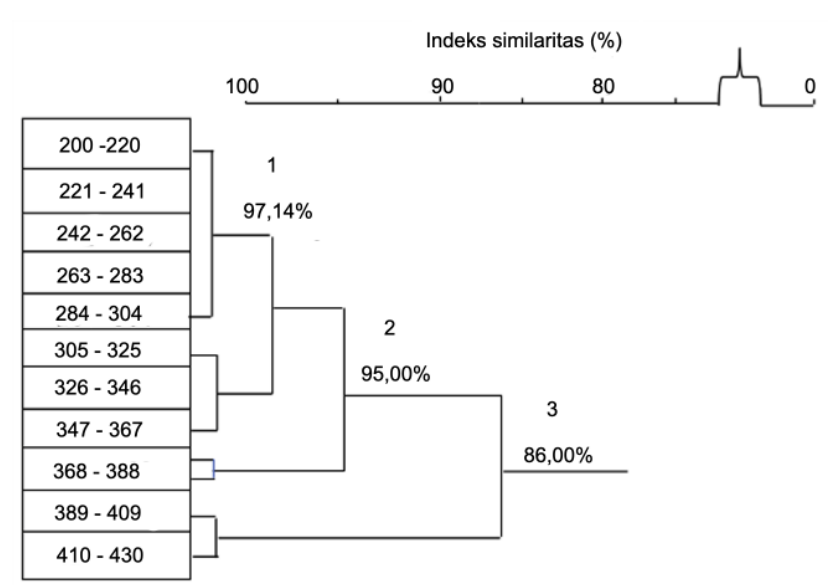

Gambar 4 Pengelompokan ukuran ikan gabus di Perairan Rawa Aopa

patan habitat berdasarkan kelompok ukuran tersebut, juga dilaporkan oleh Shireman \& Smith (1983) pada ikan koan (Ctenopharyngodon idella); Davey et al. (2005) pada ikan bullhead (Cottus gobia). Ikan berukuran larva dan juwana lebih merespons perubahan dalam tutupan kanopi tumbuhan yang dimanfaatkan sebagai pelindung. Hal ini menunjukkan bahwa tumbuhan air berperan penting dalam menunjang pertumbuhan ikan gabus. Ikan berukuran 200-367 merupakan kelompok ikan yang produktif, artinya ikan tersebut berada dalam fase perkembangan gonad sehingga membutuhkan asupan nutrisi yang cukup besar dalam mendukung perkembangan gonadnya. Saat dalam perkembangan gonad, ikan sangat bergantung pada ketersediaan makanan sebagai sumber energi untuk perkembangan organ reproduksinya, yaitu peningkatan bobot ovarium yang berhubungan dengan proses vitelogenesis dan peningkatan bobot testes yang berhubungan dengan proses spermatogenesis dan peningkatan volume semen dalam tubulus seminiferi (Asriyana \& La Sara 2013).

Ikan yang berukuran $368-388$ dan $389-430 \mathrm{~mm}$ juga selalu ditemukan (konsisten) pada habitat dengan kerapatan tumbuhan air yang jarang dan tidak konsisten pada habitat dengan tumbuhan air yang rapat. Bahkan ikan yang berukuran $389-430 \mathrm{~mm}$ tidak ditemukan pada habitat dengan tumbuhan air yang rapat. Hal ini dipengaruhi oleh tingkah laku ikan gabus saat berukuran dewasa, yaitu lebih suka berenang sendirian atau berkelompok dan mampu menangkap 


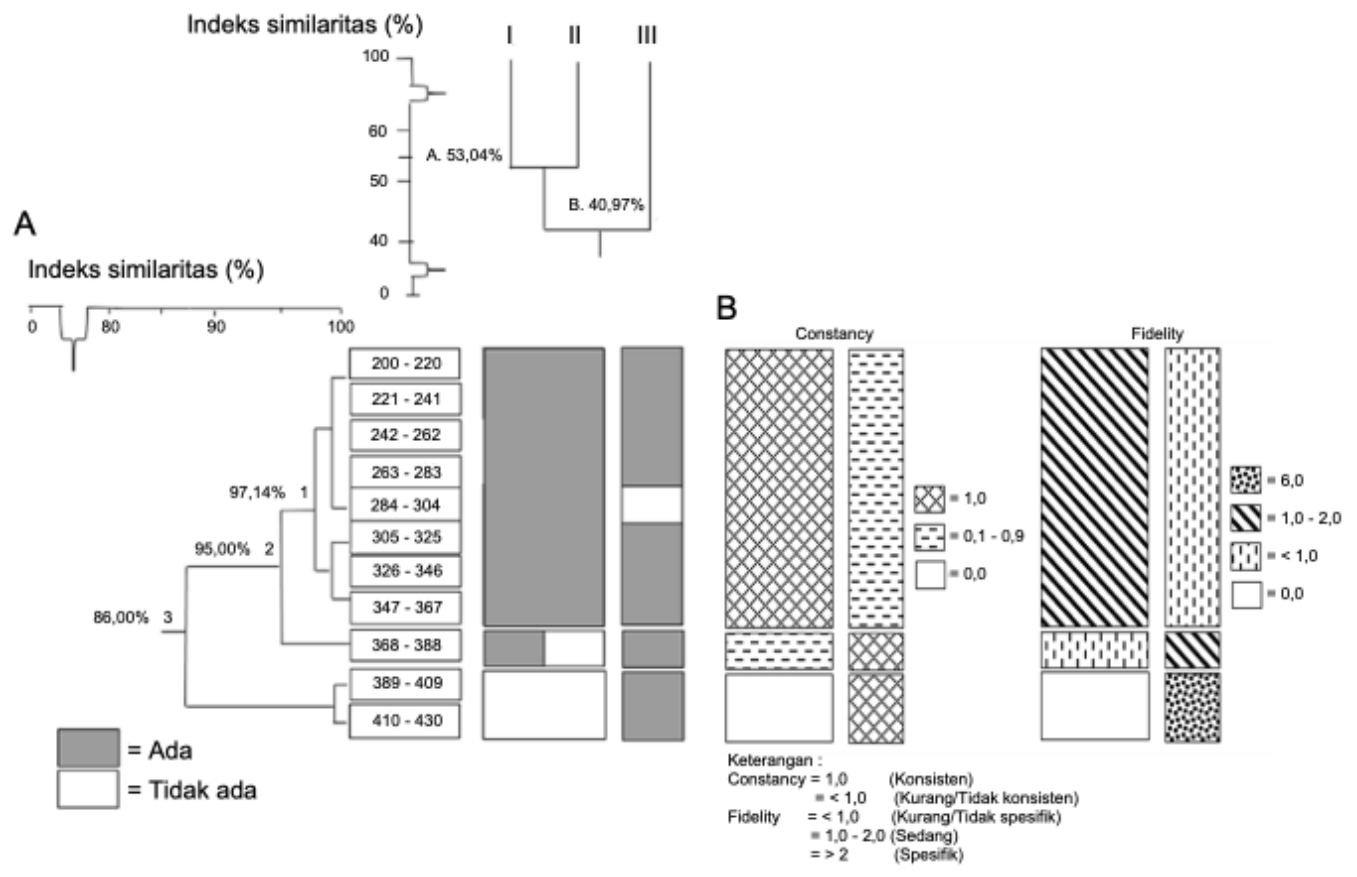

Gambar 5 Matriks data biner hasil kombinasi antara kelompok habitat dan kelompok ukuran ikan gabus di perairan (A); Proporsi constancy dan fidelity setiap komponen matriks berdasarkan analisis nodal di perairan Rawa Aopa (B)

mangsa lebih besar daripada ukuran yang lebih kecil sehingga menyukai habitat dengan tumbuhan air yang jarang. Selain itu diduga bahwa ikan gabus ukuran tersebut merupakan ikan berumur tua, yang mempunyai laju pertumbuhan yang lambat daripada ikan berumur muda dan produktif sehingga kebutuhan nutrisinya tidak terlalu tinggi dibandingkan ikan berumur muda. Kebutuhan makanan pada ikan berumur tua hanya digunakan sebagai sumber energi dan pemeliharaan tubuh saja. Hal ini diduga merupakan salah satu penyebab ikan yang berumur tua konsisten pada habitat dengan kerapatan tumbuhan air jarang dengan ketersediaan sumber daya makanan yang lebih rendah daripada habitat dengan tumbuhan air yang rapat.

Tingkat kesukaan ikan gabus ukuran $389-430 \mathrm{~mm}$ pada habitat dengan tumbuhan air jarang sangat tinggi $\left(F_{i j}=6\right)$ dan dapat dijadikan sebagai ukuran indikator pada habitat dengan kategori tumbuhan air jarang. Sementara ukuran 200-367 dan 368-388 mm mempunyai tingkat kesukaan sedang berturut-turut pada habitat bertumbuhan air rapat dan jarang $\left(F_{i j}=1-2\right)$. Ukuran $389-430 \mathrm{~mm}$ terlihat tidak menyukai habitat dengan kategori tumbuhan rapat $\left(F_{i j=0}\right)$. Hal ini karena ukuran tersebut tidak memerlukan habitat dengan kategori tumbuhan rapat untuk bersembunyi maupun dalam menyergap mangsanya, berbeda dengan ikan gabus yang berukuran lebih kecil. Di samping itu, ikan gabus ukuran tersebut juga memangsa ikan yang berukuran lebih besar, dan ikan-ikan tersebut biasa tinggal di habitat dengan tanaman yang tidak terlalu rapat.

Kesukaan ikan gabus pada habitat berkait erat dengan upaya mencari kondisi terbaik bagi kelangsungan hidupnya. Pemanfaaan habitat tersebut disesuaikan dengan orientasi ikan, apakah untuk mencari makan, berpijah, atau untuk berlindung dari predator. Saat ikan berukuran 200-367 mm, penempatan habitat ditujukan untuk mencari makan sehingga habitat yang dipilih merupakan habitat dengan ketersediaan makanan yang melimpah, yaitu habitat dengan kerapatan tumbuhan air dengan kategori rapat. Pemilihan habitat oleh kelompok ukuran ikan gabus juga ditemukan pada ikan silver kob (Argyrosomus inodorus) di perairan Namibia (Kirchner \& Holtzhausen 2001), Apletodon dentatus (Gonc, alves et al. 2002), dan Dissosticus mawsoni (Near et al. 2003). Pola penempatan habitat spasial tersebut berkaitan dengan morfologi, fisiologi, dan perilaku (Pittman \& McAlpine 2001), kemampuan renang (Davey et al. 2005), ketersediaan makanan (Hughes \& Dill 1990; Hill \& Grossman 1993; Davey et al. 2005), keterlindungan (Gonc,alves et al. 2002), dan ketersediaan habitat pemijahan (Kirchner \& Holtzhausen 2001).

\section{KESIMPULAN}

Tingkat kesukaan ikan gabus pada habitat sangat erat kaitannya dengan upaya mencari kondisi terbaik bagi kelangsungan hidupnya. Pola penempatan habitat tersebut berkaitan dengan morfologi, ketersediaan makanan, dan keterlindungan. Kesukaan ikan ukuran 200-367 mm pada habitat dengan tumbuhan air yang rapat mengindikasikan bahwa habitat tersebut perlu dilindungi sebagai wilayah mencari makanan, pembesaran, dan perlindungan. Ketidakberpihakan pada upaya tersebut dapat menurunkan populasi ikan gabus 
di perairan bahkan pada kondisi ekstrem dapat menyebabkan hilangnya sumber daya tersebut sehingga akan mengubah kestabilan komunitas ikan di perairan Rawa Aopa.

\section{UCAPAN TERIMA KASIH}

Penulis mengucapkan terima kasih kepada Program Studi IImu Perikanan Pascasajana dan Fakultas Perikanan dan Ilmu Kelautan Universitas Halu Oleo atas seluruh dukungan fasilitas dalam penyelesaian penelitian ini.

\section{DAFTAR PUSTAKA}

Anwar K, Bijaksana U, Herliwati, Ahmadi. 2018. Oodev injection frequency and time period in advancing gonad rematuration of snakehead (Channa striata Blkr) in hapa system. International Journal of Environment, Agriculture and Biotechnology. 3(3): 1114-1123. https://doi.org/10.22161/ijeab/3.3.52

Arsyad R, Asriyana, Irawati N. 2018. Variasi ontogenetik makanan ikan gabus (Channa striata) di perairan Rawa Aopa Watumohai Kecamatan Angata Kabupaten Konawe Selatan. Jurnal Manajemen Sumber Daya Perairan. 3(2): 143-149.

Asriyana, La Sara. 2013. Beberapa aspek biologi reproduksi ikan siro (Sardinella longiceps Val.) di Perairan Teluk Kendari, Sulawesi Tenggara. Jurnal Iktiologi Indonesia. 13(1): 1-11. https://doi.org/10.3 2491/jii.v13i1.107

Asriyana, Irawati N, Indrayani. 2018 Trophic ecology of twoblotch ponyfish Nuchequula blochii in Kendari Bay, Southeast Sulawesi, Indonesia. Aquacultur, Aquarium, Conservation \& Legislation Bioflux. 11(1): 66-82.

Asriyana A, Halili H. 2021. Reproductive traits and spawning activity of striped eel catfish (Plotosidae) in Kolono Bay, Indonesia. Biodiversitas. 22(7): 3020-3028. https://doi.org/10.13057/biodiv/d2207 56

Bahrin N, La Sara, Asriyana. 2020. Population parameters and exploitation level of striped snakehead, Channa striata (Bloch, 1793) in Aopa Swamp Waters, Southeast Sulawesi. Aquasains. 8(2): 829-839. https://doi.org/10.23960/aqs.v8i2. p829-840

Borah S, Gogoi P, Bhattacharjya BK, Suresh VR, Yadav AK, Baitha R, Koushlesh SK, Kakati A, Ray BC, Das BK. 2018. Length-weight and length-length relationship of two endemic snakehead fish species from Brahmaputra river basin, Assam, India. Journal of Applied Ichthyology. 34(3): 788-790. https://doi.org/10.1111/jai.13685
Brower JE, Zar JH, von Ende C. 1990. Field and Laboratory Methods for General Zoology. Third edition. United States of America (US): W.M.C Brown Publisher.pp. 160-162.

Chandra S, Banerjee TK. 2004. Histopathological analysis of the respiratory organs of Channa striata subjected to air exposure. Veterinarski archiv. 74: 37-52.

Davey AJH, Hawkins SJJ, Turner GF, Doncaster CP. 2005. Size-dependent microhabitat use and intraspecific competition in Cottus gobio. Journal of Fish Biology. 67: 428-443. https://doi.org/10.1111/ j.0022-1112.2005.00736.x

Dayal R, Srivastava PP, Bhatnagar A, Chowdhary S, Lakra WS, Raizada S, Yadav AK. 2012. Comparative study of WLR of Channa striatus fryfingerling, grow-outs and adults of gangetic plains. Online Journal of Animal and Feed Research. 2(2): 174-176.

Djumanto, Probosunu N, Styobudi E, Erka AN. 2018. Karakteristik habitat ikan gabus (Channa striata Bloch, 1793) di Rawa Pening Kabupaten Semarang. Laporan Penelitian. Yogyakarta (ID): Departemen Perikanan Fakultas Pertanian UGM. $43 p$.

Duan T, Shi C, Zhou J, Lv X, Li Y, Luo Y. 2018. How does the snakehead Channa argus survive in air? The combined roles of the suprabranchial chamber and physiological regulations during aerial respiration. Biology Open. 7(2): 1-5. https://doi.org /10.1242/bio.029223

Froese R, Pauly D (editors). 2018. FishBase. World Wide Web electronic publication [Internet]. [diunduh 2020 Okt 28]. Tersedia pada: www.fishbase.org

Gonc,alves EJ, Miguel B, Henrique CN, Miguel $\mathrm{H}$. 2002. Ontogenetic shifts in patterns of microhabitat utilisation in the small-headed clingfish, Apletodon dentatus (Gobiesocidae). Environmental Biology of Fishes. 63: 333-339. https://doi.org/10.1023/A:10 14302319622

Gosari HA, Haris A. 2012. Studi kerapatan dan penutupan jenis lamun di Kepulauan Spermonde. Torani. Jurnal IImu Kelautan dan Perikanan. 22(3): 256-162.

Hidayati D, Faizah A, Prasetyo EN, Jadid N, Abdulgani N. 2018. Antioxidant capacity of snakehead fish extract (Channa striata) at different shelf life and temperatures. In: IOP Conference Series. Journal of Physics Conference Series. 1-5. https://doi.org/10 .1088/1742-6596/1028/1/012021

Hill J, Grossman GD. 1993. An energetic model of microhabitat use for rainbow trout and rosyside dace. Ecology. 74: 685-698. https://doi.org/10.230 7/1940796 
Hughes FN, Dill LM. 1990. Position choice by drift feeding salmonids: Model and test for arctic grayling (Thymallus arcticus) in subarctic mountain streams, interior Alaska. Canadian Journal of Fisheries and Aquatic Sciences. 47: 2039-2048. https://doi.org/ 10.1139/F90-228

Irmawati, Tresnati J, Nadiarti, Fachruddin L. 2019. Sex Differentiation and gonadal development of striped snakehead (Channa striata Bloch, 1793). In: IOP Conference Series. Earth and Environmental Science. 1-8. https://doi.org/10.1088/1755-1315/ 253/1/012007

Kirchner CH, Holtzhausen JA. 2001. Seasonal movements of silver kob, Argyrosomus inodorus, (Griffths and Heemstra) in Namibian waters. Fisheries Management and Ecology. 8: 239-251. https://doi.org/10.1046/j.1365-2400.2001.00243.x

Kottelat M, Kartikasari SN, Whitten T, Wirjoatmodjo S.1993. Freshwater Fishes of Western Indonesia and Sulawesi (lkan Air Tawar Indonesia Bagian Barat dan Sulawesi). Singapore (SG): Periplus Editions. 461p.

Krebs CJ. 1989. Ecological Methodology. New York (US): Addison Wesley Longman. 620 p.

Lalramliana, Knight JDM, Van Lalhlimpuia D, Singh M. 2018. Integrative taxonomy reveals a new species of snakehead fish, Channa stiktos (Teleostei: Channidae), from Mizoram, North Eastern India. Vertebrate Zoology. 68(2): 165-175.

La Sara, Asriyana. 2012. Studi ekologi dan biologi reproduksi ikan siro di perairan Teluk Kendari Sulawesi Tenggara. Laporan Penelitian Pakar. Fakultas Perikanan dan IImu Kelautan, Universitas Halu Oleo.

Legendre L, Legendre P. 1983. Numerical Ecology. Developments in environmental modelling. Amsterdam (NL): Elsevier Scient. Publ. Co. 419 p. https://doi.org/10.1007/978-3-642-69024-2_56

Li K, Shieh B, Chiu Y, Huang D, Liang S. 2016. Growth, Diet Composition and Reproductive Biology of the Invasive Freshwater Fish Chevron snakehead Channa striata on a Subtropical Island. Zoological Studies. 55: 53. http://dx.doi.org/10.6620/ZS.201 $6.55-53$

Li Q, Xu R, Huang J. 2013. Length-weight relations for 20 fish species from the Pearl River, China. Acta Ichthyologica et Piscatoria. 43(1): 65-69. http://dx.doi.org/10.3750/AIP2013.43.1.09

Makmur S, Rahardjo MF, Sukimin S. 2003. Biologi reproduksi ikan gabus (Channa striata Bloch) di daerah banjiran sungai Musi Sumatera Selatan. Jurnal Iktiologi Indonesia. 3(2): 57-62.
Moyle PB, Cech JJ. 2000. Fishes: An Introduction to Ichthyology. Fourth Edition. New Jersey (US): Prentice Hall. 612 p.

Muslim, Fitrani M, Afrianto AM. 2018. The effect of water temperature on incubation period, hatching rate, normalities of the larvae and survival rate of snakehead fish Channa striata. Aquacultura Indonesiana. 19(2): 90-94. https://doi.org/10.2153 4/ai.v19i2.124

Mustafa A, Widodo MA, Kristianto Y. 2012. Albumin and zinc content of snakehead fish (Channa striata) extract and its role in health. IEESE International Journal of Science and Technology. 1(2): 1-8.

Muthmainnah N. 2013. Hubungan panjang berat dan faktor kondisi ikan gabus (Channa striata Bloch, 1793) yang dibesarkan di rawa lebak, Provinsi Sumatera Selatan. Depik. 2(3): 184-190.

Ndobe S, Serdiati N, Moore A. 2014. Domestication and Length-Weight Relationship of Striped Snakehead Channa striata (Bloch). International Conference of Aquaculture Indonesia 2014. https: //doi.org/10.31230/osf.io/yv6ne

Near TJ, Russo SE, Jones CD, DeVries AL 2003. Ontogenetic shift in buoyancy and habitat in the Antarctic toothfish, Dissostichus mawsoni (Perciformes: Nototheniidae). Polar Biology. 26: 124-128. https://doi.org/10.1007/s00300-002-045 9-7

Ngoc Bich TT, Tri DQ, Yi-Ching C, Khoa HD. 2020. Productivity and economic viability of snakehead Channa striata culture using an aquaponics approach. Aquacultural Engineering. 89. https:// doi.org/10.1016/j.aquaeng.2020.102057

Pancho JJV, Soedani M. 1978. Aquatic Weeds of Southeast Asia. Tropical Pest Biology. Bogor (ID): Program Biotrop, Seameo. Regional Center for Biology.

Pittman SJ, McAlpine CA. 2001. Movements of marine fish and decapod crustaceans: process, theory and application. Advance in Marine Biology. 44: 205-294. https://doi.org/10.1016/S0065-2881(03) 44004-2

Prastari C, Yasni S, Nurilmala M. 2017. Karakteristik protein ikan gabus yang berpotensi sebagai antihiperglikemik. Jurnal Pengolahan Hasil Perikanan Indonesia. 20(2): 413-423. https://doi. org/10.17844/jphpi.v20i2.18109

Ridho MR, Patriono E, Haryani R. 2019. Keanekaragaman jenis ikan di perairan Lebak Jungkal Kecamatan Pampangan Kabupaten Ogan Komering Ilir pada Musim Hujan dan Kemarau. Majalah IImiah Biologi Biosfera: A Scientific Journal. 36(1): 41-50. 
Rosyidi RM, Januarman J, Priyanto B, Islam AA, Hatta M, Bukhari A. 2019. The effect of snakehead fish (Channa striata) extract capsule to the albumin serum level of post-operative neurosurgery patients. Biomedical and Pharmacololg Journal. 12(2): 893-899. https://doi.org/10.13005/bpj/1714

Serdiati N, Ndobe S, Moore A. 2013. Growth of juvenile striped snakehead (Channa striata) in a controlled environment with live feed (Aplocheilus panchax). Paper presented at the International Seminar on Maritime and Agribusiness, Tadulako University, Palu, Indonesia, 13-14 Dec 2013.

Shireman JV, Smith CR. 1983. Synopsis of Biological Data on the Grass Carp Cenopharygodon idella (Cuvier and Valenciennes, 1844). FAO Fisheries Synopsis No. 135. Food and Agricultural Organization of The United Nations.

Sirodiana, Irawan D. 2017. Pemilihan jenis tanaman air sebagai naungan pada pendederan ikan gabus (Channa striata). Buletin Teknik Litkayasa Akuakultur. 15(1): 19-23. https://doi.org/10.15578 /blta.15.1.2017.19-23
Sturges H.A. 1926. The choice of a class interval. Journal American Statistical Association. 21: 65-66. https://doi.org/10.1080/01621459.1926.10502161

Suhendi A, Pawarti $H$, Rohman A, Wahyono D, Nurrochmad A. 2020. Snakehead fish extract (Channa striata): A review of pharmacological activity. Eurasian Journal of Biosciences. 14(2).

Taufikir, Asriyana, Irawati N. 2018. Produktivitas ikan gabus (Channa striata) di perairan Rawa Aopa Watumohai Desa Pewutaa Kecamatan Angata Kabupaten Konawe Selatan. Jurnal Manajemen Sumber Daya Perairan. 3(1): 55-60.

Ward-Campbell MS, Beamish FWH. 2005. Ontogenetic changes in morphology and diet in the snakehead, Channa limbata, a predatory fish in western Thailand. Environmental Biology of Fishes. 72(3): 251-257. https://doi.org/10.1007/s10641-00 4-1744-9

Weliange WS, Amarasinghe US. 2007. Relationship between body shape and food habits of fish from three reservoirs of Sri Lanka. Asian Fisheries Science. 20: 257-270. https://doi.org/10.33997/j.af s.2007.20.3.003 